
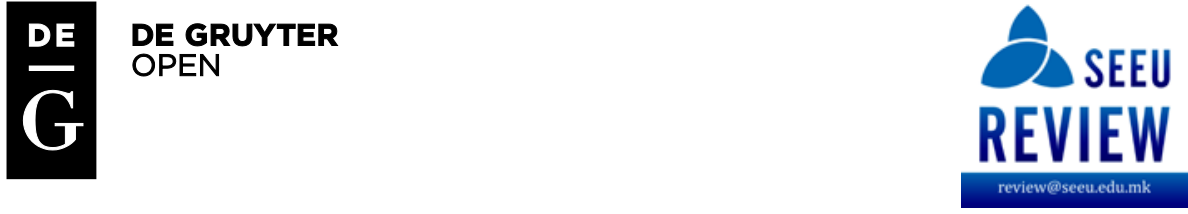

\title{
Sudden stops and current account reversals: the euro area experience
}

\section{Vesna Georgieva Svrtinov,}

$\mathrm{PhD}$, "Ss. Cyril and Methodius University" Skopje, Institute of Economics

- Skopje, St. Prolet 1, Republic of Macedonia,

e-mail: vesna@ek-inst.ukim.edu.mk.

\section{Olivera Gorgieva-Trajkovska,}

PhD, “Goce Delcev University” Faculty of Economics, St. Krste Misirkov 10/A Stip, Republic of Macedonia, e-mail: olivera.trajkovska@ugd.edu.mk.

\section{Riste Temjanovski,}

$\mathrm{PhD}$, “Goce Delcev University” Faculty of Economics, St. Krste Misirkov 10/A Stip, Republic of Macedonia, e-mail: riste.temjanovski@ugd.edu.mk

\section{DOI: $10.1515 /$ seeur-2015-0026}

\begin{abstract}
The paper analyzes the impact of massive capital flows and possible sudden stops on current account reversals. The aim of this paper is to consider the relationship between sudden stops and current account reversals in the eurozone and to explain the possibility of a balance-of-payment crisis within a monetary union.

Peripheral eurozone countries experienced significant private-capital inflows from the core countries, followed by unambiguously massive outflows. Due to this, peripheral countries ran sustained current account deficits while core countries ran surpluses.

At the end we analyze the evolution of current-account balances in the noneuro area EU countries and the peripheral euro-area countries, and we find out
\end{abstract}


that current account deficits could be maintained over a longer period of time in the peripheral euro-area countries.

Key words: capital flows, sudden stops, current account reversals, euro zone

\section{Capital flows, sudden stops and current account reversals}

The liberalization of the capital account of the balance of payments was one of the main reasons of the increasing amount of capital flows that came into many emerging economies. In the last decades, the restrictions on these capital movements have been eliminated and the world has witnessed the creation of a liberalized environment.

But through this history there were examples when free capital mobility produced macroeconomic instability and contributed to financial vulnerability in the emerging nations. In a world of high capital mobility "sudden stops" of capital inflows can be highly disruptive, because they tend to result in major current account reversals, and in costly adjustment processes.

Sudden stops are an abrupt slowdown of private capital inflows into an economy, due to new information about the capability of a country to honour its financial obligations. It is usually very disruptive to an economy, since it forces an almost immediate reversal in the current account from an external deficit to a surplus one. Current account reversals are broadly defined as "a major reduction in the current account deficit that takes place within a year or two" (Edwards, 2004).

We have to take into account that current account reversals are more likely to occur in countries with persistent deficit, low reserves and unfavourable terms of trade, than in the countries that receive high official transfers.

Experience has shown that sudden stops of capital flows and current account reversals have been closely related.

Net capital inflows are the counterpart of current account deficits.

Excessive net inflows may be an indication that the economy is running an $\mathrm{u}$ nsustainable current account deficit. In this context, "excessive" capital mobility can be highly disruptive and restricting the degree of capital mobility will reduce the probability of a sudden stop and a current account reversal. 
But, throughout history there have been many sudden stops that have not been related to reversal episodes. This indicates that when facing a sudden stop, many countries have effectively used their international reserves to avoid an abrupt current account adjustment. At the same time, a number of countries have gone through major current account reversals without facing a sudden stop in inflows. Most countries in this group were not receiving large inflows to begin with, and had financed their large deficits by drawing down international reserves.

\section{Capital flows, sudden stops and current account reversals in EMU}

One of the principal goals of Europe's common currency has always been to promote greater financial market integration among member countries. It was expected that the common currency would make it easier for investors of certain euro countries to find good investment opportunities in other euro countries, since they would no longer have to worry about fickle exchange rates. The euro had created a low-inflation, low-interest-rate environment conducive to sustainable growth. It had fostered trade integration and the integration of financial markets among the members of the euro area.

Furthermore, the single currency was expected to make balance of payments irrelevant between the euro-area member states. It seems awkward to speak of balance-of-payments crises within a monetary union that was designed to make such crises impossible.

According to Ingram (1973), in a monetary union "payments imbalances among member nations can be financed in the short run through the financial markets, without need for interventions by a monetary authority. It was believed that a major effect of EMU is that balance-of-payments constraints will disappear. Private markets will finance all viable borrowers, and savings and investment balances will no longer be constraints at the national level”. At the time of the inception of the euro-area, a prevailing view was that current-account imbalances among participating countries should not be a major concern in a monetary union. Among euro-area countries, balance-ofpayments would become as irrelevant as among regions within a country.

Soon after the creation of the Economic and Monetary Union significant amounts of capital started to flow from what are today called the core countries to the periphery of the euro-area. Countries like Greece, Ireland, Spain, Portugal and Italy seemed to offer attractive investment opportunities relative to the economies of the core (Germany, France, Austria) and there was no 
longer risk associated with the exchange rate. Also, there was widespread optimism concerning the expectation of rapid income growth resulting from joining the euro. The elimination of the exchange rate risk appeared beneficial for both borrowers and lenders. Everything was being seen as a part of a wellfunctioning monetary union, which was designed to make a balance of payment crisis impossible.

Capital flew from countries with abundant capital, and thus relatively low returns on investments, to countries that were relatively capital-poor, and that therefore offered high returns on investments. Core eurozone countries, like Germany, France, Austria, took advantage of relatively high rates of return in the periphery, see table 1 .

\begin{tabular}{|c|c|c|c|c|c|c|c|c|c|c|}
\hline Year & $\mathbf{2 0 0 4}$ & $\mathbf{2 0 0 5}$ & $\mathbf{2 0 0 6}$ & $\mathbf{2 0 0 7}$ & $\mathbf{2 0 0 8}$ & $\mathbf{2 0 0 9}$ & $\mathbf{2 0 1 0}$ & $\mathbf{2 0 1 1}$ & $\mathbf{2 0 1 2}$ & $\mathbf{2 0 1 3}$ \\
\hline Greece & 4.26 & 3.59 & 4.07 & 4.5 & 4.8 & 5.17 & 9.09 & 15.75 & 22.5 & 10.05 \\
\hline Italy & 4.26 & 3.55 & 4.05 & 4.49 & 4.68 & 4.31 & 4.04 & 5.42 & 5.49 & 4.32 \\
\hline Spain & 4.10 & 3.39 & 3.78 & 4.31 & 4.36 & 3.97 & 4.25 & 5.44 & 5.85 & 4.56 \\
\hline Germany & 4.04 & 3.35 & 3.76 & 4.22 & 3.98 & 3.22 & 2.74 & 2.61 & 1.5 & 1.57 \\
\hline France & 4.1 & 3.41 & 3.8 & 4.3 & 4.23 & 3.64 & 3.12 & 3.32 & 2.54 & 2.2 \\
\hline Austria & 4.13 & 3.4 & 3.8 & 4.3 & 4.36 & 3.94 & 3.22 & 3.32 & 2.37 & 2.01 \\
\hline
\end{tabular}

Table 1. Long-term European interest rates, Total, \% per annum (2004-2013) Source: OECD database.

But, as we can see from Table 1, in the years after the crisis, interest rates in the peripheral countries continue to rise more rapidly than in core countries. The most evident case is in Greece, where interest rates reached a record level of $22.5 \%$ in 2012. Due to this, peripheral countries encountered difficulties to finance their budget deficits via financial markets. This increased the probability of a sovereign default or even an exit from the euro-area.

The capital flows into a country are measured by its current account deficit-a negative current account deficit means that the country is the recipient of international lending, while a surplus indicates that capital is being invested abroad. Many of the Southern European members ran sustained current account deficits while the Northern members ran surpluses (see chart 1). A basic assumption in the economy is that if a country is running a current account deficit, this is "balanced up" or "financed" by seeking to run a capital account deficit. From this point, core countries experience a deficit in capital account, while peripheral countries surplus (see chart 2). 


\section{Current account Balance (BoP, current US\$)}

$4 \mathrm{E}+11$

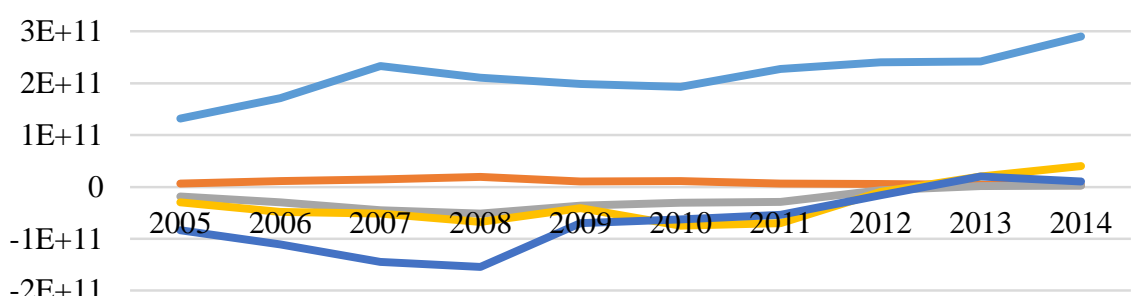

$-2 \mathrm{E}+11$

Germany $\longrightarrow$ Austria $\longrightarrow$ Greece Italy $\longrightarrow$ Spain

\section{Chart 1.}

Source: OECD database.

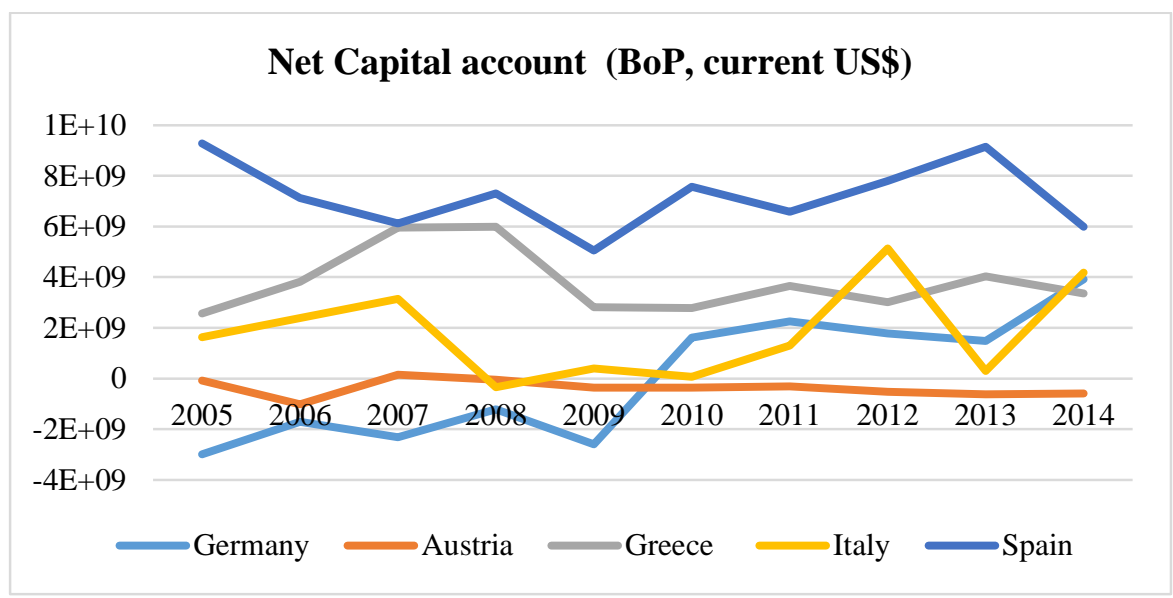

Chart 2.

Source: OECD database.

Although the country's large current-account deficits signalled a competitiveness problem, capital continued to flow into the peripheral countries until 2008-2009, pushing up money and credit growth which, in turn, increased the inflation. Macroeconomic imbalances occurred in the form of large and persistent current account deficits, which had increased the accumulation of external debt and deteriorated the competitiveness of these countries compared to the core countries.

But, with the beginning of the global financial crisis in 2008, despite the solid economic fundamentals in emerging market economies, the lack of liquidity made international banks and investors withdraw portfolio investments from these economies. The sudden stop which happened in 2009 
made it difficult for these countries to roll over debt, and thus caused a crisis. (Svrtinov at al, 2014).

\section{Current account reversal in periphery euro-area and non euro-area EU countries}

The table below reports the evolution of current-account balances in the non euro-area EU countries and the peripheral euro-area countries. It is apparent that the two groups of countries have not followed the same path: whereas adjustment has been brutal for the first group, with deficits amounting to 12 to 22 percent of GDP transformed into surpluses over one, two or three years, it has been more slow for the second group of countries. This means that current-account adjustments after the crisis have been slower in euro-area countries than in non-euro-area EU countries, which undergo a profound adjustment process to correct their external position, mainly by reducing private and public expenditure. The financing channel available through the Eurosystem protected the banking systems of the countries in the euro-area from the immediate effects of a sudden stop in private capital flows. Substantial current account deficits could thus be maintained over a longer period of time in the peripheral euro-area countries (Ferry and Merler, 2012).

\begin{tabular}{|c|c|c|c|c|c|c|c|c|c|}
\hline Year & 2006 & 2007 & 2008 & 2009 & 2010 & 2011 & 2012 & 2013 & 2014 \\
\hline Spain & -8.8 & -9.8 & -9.5 & -4.7 & -4.4 & -3.6 & -1.2 & 1.4 & 0.8 \\
\hline Greece & -10.8 & -14 & -14.5 & -10.9 & -10.1 & -9.9 & -2.5 & 0.6 & 0.9 \\
\hline Italy & -2.5 & -2.3 & -2.8 & -1.9 & -3.5 & -3.1 & -0.4 & 0.9 & 1.9 \\
\hline Portugal & -10.7 & -9.8 & -12.2 & -10.4 & -10.2 & -6.1 & -2.1 & 1.4 & 0.6 \\
\hline Latvia $^{1}$ & -20.9 & -20.8 & -12.6 & 8.2 & 2.4 & -2.8 & -3.2 & -2.3 & -3.1 \\
\hline Lithuania $^{2}$ & -10.4 & -14.6 & -13.4 & 2.3 & -0.3 & -3.8 & -1.2 & 1.6 & 0.1 \\
\hline Bulgaria $^{2}$ & -17.4 & -26.2 & -22.3 & -8.5 & -1.6 & 0.2 & -0.9 & 1.8 & 0.9 \\
\hline
\end{tabular}

Table 2. Current account balance (\% of GDP) in EMU and non euro-area countries

Source: World Bank database.

The injection of liquidity has helped to accommodate persistent currentaccount adjustments in the southern part of the euro-area, but what is most important, it has protected countries that could no longer rely on adjusting their exchange rates from the full negative impact of a sudden stop. We have to take into account that in EMU, countries cannot carry out currency devaluation because they have the euro and they give up the opportunity to

\footnotetext{
${ }^{1}$ In that period Latvia was not part of EMU

${ }^{2}$ In that period Lithuania was not part of EMU
} 
select a monetary policy that is regarded as optimal for their own circumstances.

The observed private capital outflows have been counteracted by equally sizable public capital inflows, which have taken three forms in the euro-area: EU/IMF assistance programs; provision by the Eurosystem of liquidity to the banking sector; and ECB purchases of sovereign bonds under the Securities Market programme.

Substitution of private capital inflows by public ones, especially Eurosystem financing, has provided a buffer against the drying up of private liquidity and to some extent has helped to accommodate persistent currentaccount deficits.

But, due to massive bailouts, which have run into the hundreds of billions of euros, as well as high interest rates, peripheral EMU countries have faced debt crises. The maximum debt allowed by the European Union is 60 percent of gross domestic product. None of the countries in the table 3 have met this standard. Even in the core countries, government debt as a percent of GDP was higher than 60 percent. In peripheral countries, government debt was more than 100 percent of GDP.

\begin{tabular}{|l|l|l|l|l|l|l|l|l|l|l|l|}
\hline Year & $\mathbf{2 0 0 4}$ & $\mathbf{2 0 0 5}$ & $\mathbf{2 0 0 6}$ & $\mathbf{2 0 0 7}$ & $\mathbf{2 0 0 8}$ & $\mathbf{2 0 0 9}$ & $\mathbf{2 0 1 0}$ & $\mathbf{2 0 1 1}$ & $\mathbf{2 0 1 2}$ & $\mathbf{2 0 1 3}$ & $\mathbf{2 0 1 4}$ \\
\hline Germany & 67.7 & 70.3 & 68.4 & 64.3 & 68.1 & 75.6 & 84.1 & 83.5 & 86.4 & 81.6 & 82.2 \\
\hline France & 80 & 81.7 & 76.9 & 75.6 & 81.5 & 93.2 & 96.8 & 100.7 & 110.6 & 110.4 & \\
\hline Austria & 71.3 & 75.8 & 72.4 & 68.7 & 74 & 79.9 & 85.2 & 86.9 & 91.8 & 89.2 & 98.1 \\
\hline Greece & 107.6 & 111.4 & 115.8 & 113.1 & 117.4 & 134.8 & 128.3 & 110.3 & 164.4 & 179.7 & 178.2 \\
\hline Italy & 114.6 & 117.4 & 115 & 110.6 & 112.9 & 125.9 & 124.8 & 117.8 & 136 & 143.2 & 156.2 \\
\hline Spain & 52.5 & 50 & 45.7 & 41.7 & 47.1 & 61.7 & 66.5 & 77.2 & 91 & 102 & 115.5 \\
\hline
\end{tabular}

Table 3. General government debt, total, as a \% of GDP

Source: OECD database.

Moreover, efforts to reduce governmental deficits by i.e. higher taxes and/or lower expenses faced strong social resistance in the weak countries. Meanwhile, euro-area leaders and the ECB also installed some supra-national arrangements to prevent contagion and endangerment of the euro itself.

But, the relationship between budget deficit and crisis is weaker. The factor that crisis countries have in common is that, without exception, they ran the largest current account deficits in the euro zone during the period 2000-2007. The relationship between budget deficits and crisis is much weaker; some of the crisis countries had significant average surpluses during the years leading up to the crisis, while some of the euro zone countries with large fiscal deficits did not experience crisis. 


\section{Summary}

Sudden stops of capital inflows are defined as a situation where the flow of capital coming into a country is reduced significantly in a very short period of time and current account reversals are major reductions in the current account deficit that take place within a year or two. Experience has shown that sudden stops of capital flows and current account reversals have been closely related.

Current account reversals are more likely to occur in countries with persistent deficit, low reserves and unfavourable terms of trade, than in the countries that receive high official transfers.

Euro adoption encouraged a capital flow bonanza from the countries which constitute the centre of the Eurozone, to the countries which make up the periphery of the Eurozone, where it was possible to obtain better returns, due to their less developed financial systems. This explains the large current account surplus in the euro core countries and the deficits in the euro peripheral countries. The current account positions of some of the euro-area's peripheral members have fallen. Large and persistent current account deficits contributed to a large accumulation of external debt and were accompanied by a generalized deterioration of the competitiveness relative to other euro areacore countries. On the other side, core countries experience deficit in capital accounts, while peripheral countries experience surplus.

But, with the beginning of the crisis, the financial institutions from the core countries stricken by the crisis started to withdraw capital massively from their affiliates located in the peripheral countries, which caused a negative influence over foreign exchange reserves and even over the liquidity crises in these economies.

The current account deficit in the peripheral EMU countries has adjusted only partially, given the important role of euro system financing. When compared to other countries outside the monetary union, the adjustment when facing a sudden stop was much faster and sharper, i.e. the adjustment was quicker outside EMU than inside it. Substantial current account deficits could thus be maintained over a longer period of time in the peripheral euro-area countries.

Given the level of integration of euro-area financial markets, the effects of unmitigated sudden stops in Southern Europe would have endangered the entire system and put at risk the survival of the single currency. 


\section{References:}

1. Cociuba, S.E. (2011), "Upstream capital flows: Why emerging markets send savings to advanced economies". In: Federal Reserve Bank of Dallas, Research Publication Vol. 6, No. 5, May 2011, (http://www.dallasfed.org/pages/research/eclett/2011/el1105.cfm.

2. Edwards, S. (2004), "Financial Openness, Sudden Stops and Current Account Reversals” In: National Bureau of Economic Research, NBER Working Paper No. 10277, February, (http://www.nber.org/papers/w10277).

3. European Central Bank (2012), "Euro area cross-border financial flows". Monthly Bulletin, February, (http://www.ecb.Europa.eu/pub/pdf/mobu/mb201202en.pdf).

4. Ferry, J. and Merler, S. (2012), "Sudden stops in the Eurozone". In: In VoxEU CEPR's Policy Portal, Working Paper, April (http://www.voxeu.org/article/public-capital-flows-replacing-privateflows-Eurozone-what-it-means-policy).

5. Ingram, J. (1973), "The case for European monetary integration", Princeton University, Essays in International Finance, April, (https://www.princeton.edu/ ies/ies_essays/e98.pdf)

6. Krugman, P. (2012), “The perils of pointless pain”. In: The New York Times, September, 26, (http://krugman.blogs.nytimes.com/2012/09/26/Euro-update-the-perilsof-pointless-pain).

7. Krugman, P. (2013), “Currency Regimes, Capital Flows, and Crises” In: Princeton University, 14th Jacques Polak Annual Research Conference, November 7-8, (https://www.imf.org/external/np/res/seminars/2013/arc/pdf/Krugman.p df).

8. Lane, P.R. (2013), “Capital Flows in the Euro Area," In: European Commission, European Economy, Economic Papers, No.497, April 2013,

(http://ec.europa.eu/economy_finance/publications/economic_paper/20 13/pdf/ecp497_en.pdf).

9. Mansori, K. (2011), “What really caused the Euro zone crisis?” In: The Street

Light,

September, 
(http://streetlightblog.blogspot.com/2011/09/what-really-causedEurozone-crisis-part.html).

10. Petkovski, M. and Georgieva, V. (2012). “The impact of capital controls on maintaining macroeconomic and financial stability in emerging market economies”. In: TASAM Turkish Asian Center for Strategic Studies, May 25 , (http://www.tasam.org/en/Icerik/4797/the_impact_of_capital_controls_ on_maintaining_macroeconomic_and_financial_stability_in_emerging_ market_economies).

11. Reinhart, C. and Reinhart, M.V. (2008), "From capital flow bonanza to financial crash”, In: VoxEU CEPR's Policy Portal, Working Paper, October 28 (http://www.voxeu.org/article/capital-inflow-bonanzafinancial-crash-danger-ahead-emerging-markets).

12. Sinn, H. (2012). “The European balance of payment crisis”. CESifo Forum, (http://ideas.repec.org/a/ces/ifofor/v13y2012ispecialissuejanuary2012p0 3-10.html).

13. Svrtinov, G.V., Trajkovska G.O and Temjanovski, R. (2014). "Cost and Benefits of Adopting Euro" In: Applied Sciences and Business Economics, Volume 1, Issue 3, p.57-64, (www.bzujournal.org/archives/volume-1-issue-3).

14. Svrtinov V.G. at al (2014), "The Flow of Capital and the Eurozone Crisis" In: International Journal of Sciences: Basic and Applied Research, (http://gssrr.org/index.php?journal=JournalOfBasicAndApplied). 